\title{
Evaluation of Air Contamination in Orthopaedic Operating Theatres in Hospitals in Southern Italy: The IMPACT Project
}

\author{
Maria Teresa Montagna ${ }^{1}\left(\mathbb{D}\right.$, Serafina Rutigliano ${ }^{1}$, Paolo Trerotoli ${ }^{1}$, Christian Napoli $^{2}(\mathbb{D}$, \\ Francesca Apollonio ${ }^{1}$, Alessandro D'Amico 1,3 ${ }^{\mathbb{D}}$, Osvalda De Giglio ${ }^{1} \mathbb{D}$, Giusy Diella ${ }^{1}$, \\ Marco Lopuzzo ${ }^{1}$, Angelo Marzella ${ }^{1}$, Simona Mascipinto ${ }^{1}$, Chrysovalentinos Pousis ${ }^{1}$, \\ Roberto Albertini ${ }^{4}$, Cesira Pasquarella ${ }^{4}$, Daniela D'Alessandro ${ }^{3}{ }^{\mathbb{D}}$, Gabriella Serio ${ }^{1}$ and \\ Giuseppina Caggiano ${ }^{1, *}$
}

1 Department of Biomedical Science and Human Oncology, University of Bari “Aldo Moro", Piazza G. Cesare 11,70124 Bari, Italy; mariateresa.montagna@uniba.it (M.T.M.); serafina.rutigliano@uniba.it (S.R.); paolo.trerotoli@uniba.it (P.T.); francesca.apo@libero.it (F.A.); alessandro.damico@uniroma1.it (A.D.); osvalda.degiglio@uniba.it (O.D.G.); giusy.diella@uniba.it (G.D.); marcolopuzzo@gmail.com (M.L.); marzella.angelo@libero.it (A.M.); simona.mascipinto@uniba.it (S.M.); vpousis@gmail.com (C.P.); gabriella.serio@uniba.it (G.S.)

2 Department of Medical and Surgical Sciences and Translational Medicine, "Sapienza" University of Rome, 0189 Rome, Italy; christian.napoli@uniroma1.it

3 Department of Civil, Building and Environmental Engineering, "Sapienza" University of Rome, 00184 Rome, Italy; daniela.dalessandro@uniroma1.it

4 Department of Medicine and Surgery, University of Parma, 43125 Parma, Italy; roberto.albertini@unipr.it (R.A.); cesiraisabellamaria.pasquarella@unipr.it (C.P.)

* Correspondence: giuseppina.caggiano@uniba.it; Tel.: +39-080-547-8475

Received: 26 July 2019; Accepted: 20 September 2019; Published: 25 September 2019

\begin{abstract}
Postoperative infections are a concern, especially in total knee and total hip arthroplasty. We evaluated the air quality in orthopaedic operating theatres in southeastern Italy to determine the level of bacterial contamination as a risk factor for postoperative infection. Thirty-five hospitals with operating theatres focused on total knee and total hip arthroplasty participated. We sampled the air passively and actively before surgeries began for the day (at rest) and $15 \mathrm{~min}$ after the surgical incision (in operation). We evaluated bacterial counts, particle size, mixed vs turbulent airflow systems, the number of doors, number of door openings during procedures and number of people in the operating theatre. We found no bacterial contamination at rest for all sampling methods, and significantly different contamination levels at rest vs in operation. We found no association between the number of people in the surgical team and bacteria counts for both mixed and turbulent airflow systems, and low bacterial loads, even when doors were always open. Overall, the air quality sampling method and type of ventilation system did not affect air quality.
\end{abstract}

Keywords: operating theatre; orthopaedic surgery; surgical site infection; air quality

\section{Introduction}

Operating theatres (OTs) are particularly complex systems in which numerous risk factors favor the onset of infectious complications. These include the structural characteristics of the facility and its organization, the patient's condition, the type of surgery, the behaviors of the surgical team, how often people enter and leave the OTs, and the efficiencies of the Heating, Ventilation and Air Conditioning (HVAC) systems [1-5]. 
Surgical site infection (SSI) is a devastating postoperative complication and has a substantial impact on morbidity and mortality. Patients with SSI have a 2-11 times higher risk of death than patients without SSI, and SSIs are associated with considerably higher costs, especially when associated with additional surgical procedures and a longer hospital stay [6-8].

In orthopaedic surgery, infection is the most common indication for revision in total knee arthroplasty and the third most common indication in total hip arthroplasty; when infection cannot be eradicated, treatment can include arthrodesis or even amputation [9]. In the USA, between 2001 and 2009, the risk of infection following hip and knee arthroplasties increased from $1.99 \%$ to $2.18 \%$ and from $2.05 \%$ to $2.18 \%$, respectively [10]. By 2030, the risk is expected to increase to $6.5 \%$ and $6.8 \%$, respectively [8,11]. In Italy, the most recent arthroplasty annual report underlined that $18.9 \%$ of knee arthroplasty revisions and $7.8 \%$ of hip revisions were secondary to infectious complications [12].

The air in OTs represents an important vehicle for microorganisms that cause SSI, especially in clean operations. After a Medical Research Council study showed a correlation between microbial air contamination and deep SSI incidence in prosthetic joint surgery, ultraclean OTs were recommended for this type of surgery [5]. Maximum air microbial contamination values were 10 colony-forming units per cubic metre $\left(\mathrm{cfu} / \mathrm{m}^{3}\right)$ when measured by active sampling and $350 \mathrm{cfu} / \mathrm{m}^{2} / \mathrm{h}$ or $2 \mathrm{cfu} / 9-\mathrm{cm}$ plate/h (IMA, index of microbial air contamination) when measured by passive sampling [13]. Based on a meta-analysis by Bishoff et al. [14], the World Health Organization (WHO) guidelines recommend against unidirectional airflow ventilation systems to reduce the risk of SSI for patients undergoing total arthroplasty surgery. However, several criticisms exist regarding the studies included in the meta-analysis; in particular, none of the studies included an assessment of microbial air contamination and assumed that the mere presence of a unidirectional airflow system guarantees its proper function. Several factors can undermine the potential benefits of this ventilation system, in particular, incorrect behaviour of the surgical team. The "Infezioni del Sito Chirurgico in Interventi di Artroprotesi" (ISChIA) study evaluating hip and knee arthroplasties showed that more than half of the passive samplings during surgical activity in unidirectional airflow ventilation OTs had values higher than $2 \mathrm{cfu} / 9-\mathrm{cm}$ plate/h, challenging the belief that unidirectional systems always provide acceptable airborne bacterial counts [15]. The same study showed that in turbulent airflow OTs (T-OTs), values much lower than the current recommended values of $180 \mathrm{cfu} / \mathrm{m}^{3}$ [16,17] and 25 IMA [18] can be obtained.

The role of airborne particles as a source of contamination has always been controversial, especially in clean surgical procedures [19]. Interpreting particle counts is based on the theory that particulate matter is considered a possible vehicle for microorganisms capable of contaminating surgical fields. The relationship between particle concentrations and microbial contamination is not yet fully accepted [20], although a recent study showed a strong correlation between air particle counts and microbial contamination, confirming that particle counts can be used for routine assessment of contamination in OTs [21].

Our study is part of a larger study, the IMPACT (IMproving the health of PAtients supporting dynamiC healTh systems and new technologies) project, promoted by the Apulia Regional Government (Southern Italy). The first part of this project, coordinated by the Department of Biomedical Sciences and Human Oncology of the University of Bari Aldo Moro (Apulia, Italy), was performed in collaboration with the Department of Civil, Construction and Environmental Engineering of Sapienza University of Rome, through a multidisciplinary and transversal approach. The first part of the study aimed to investigate whether OT design (shape, dimensions, layout and construction technology) influenced microbial air pollution [22].

The main objectives of the second part of this project were:

1. to determine the degree of microbial air contamination at a defined time (1-day study) in empty at rest) and working (in operation) OTs

2. to assess air quality in the OTs by comparing different sampling systems

3. to evaluate the association between microbiological data and particle counts with different HVAC systems. 


\section{Materials and Methods}

\subsection{Study Design}

The IMPACT project was performed from 2015-2017. Initially, a census of all of the public hospitals in the Apulia Region (southeastern Italy) was performed to select hospitals equipped with orthopaedic OTs, with a special focus on those devoted to prosthetic surgery. The medical management staff of each hospital was contacted by email to request their participation in the study on a voluntary basis and without remuneration. Ethics approval was not necessary because the study was performed on environmental samples without involving human samples or data (Legislative Decree n. 196 of 30 June 2003).

Forty-five hospitals were identified in different areas of Apulia. Of these, 39 (86.7\%) had operating areas, for a total of 287 OTs, and 35/39 (89.7\%) had 49 orthopaedic OTs. Thirty hospitals with 35 orthopaedic OTs focused on hip and knee arthroplasty operations agreed to participate in the study (Figure 1). We performed air sampling using different sampling tools, to evaluate microbial and particle diffusion.

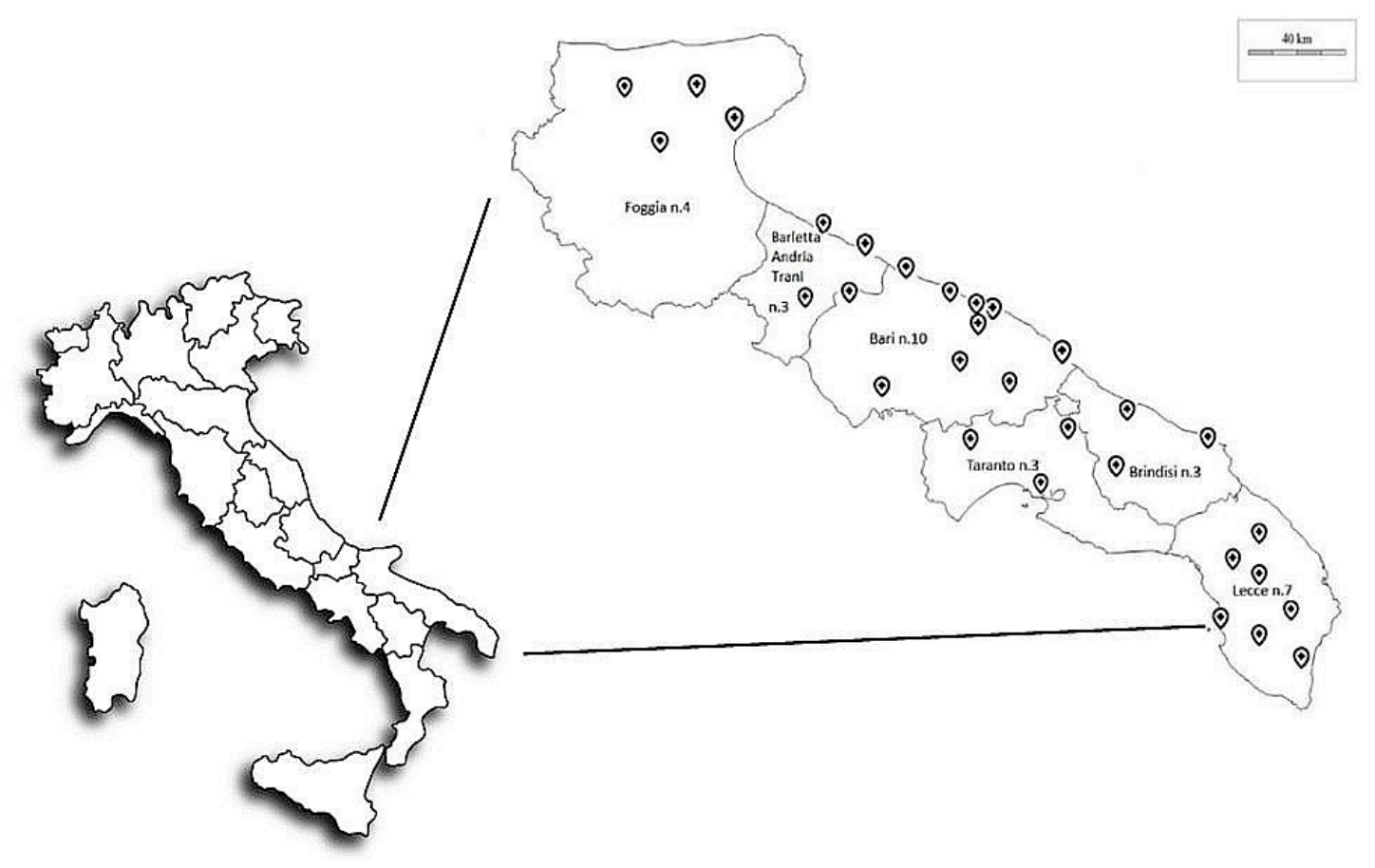

Figure 1. Location of the 30 enrolled hospitals in Apulia, Southern Italy.

\subsection{Air Sampling}

For each OT, indoor air was sampled both at rest and in operation during the first surgical procedure (hip and knee arthroplasty) of the day as follows:

(a) at rest, $1 \mathrm{~h}$ before the beginning of surgical activity, at the foot of the operative bed, to verify the efficiency of environmental cleaning systems and conditioner systems. All instruments started automatically $20 \mathrm{~min}$ after the technical team left the operating theatre.

(b) in operation, $15 \mathrm{~min}$ after the surgical incision, at the foot of the operative bed, to verify the human impact on environmental pollution. During each operation, we collected detailed information concerning the number of staff in the OTs and the number of door openings.

Microbial contamination was evaluated through active sampling to measure the concentration of microorganisms in the air, and by passive sampling to measure the rate at which viable particles settled on surfaces [23]. 
The active sampling method was performed on both solid (Surface Air System, SAS Super ISO 180; PBI International, Milan, Italy) and liquid substrates (Coriolis ${ }^{\circledR} \mu$; Bertin Technologies, Montigny le Bretonneux, France). For each sampling, $1000 \mathrm{~L}$ of air was aspirated by SAS and Coriolis ${ }^{\circledR} \mu$, which were placed approximately $1 \mathrm{~m}$ above the floor and $1 \mathrm{~m}$ from the operating bed.

For SAS, the air microbial load was evaluated using 55-mm plates containing plate count agar (PCA; Becton-Dickinson, Heidelberg, Germany). After incubation at $36 \pm 1{ }^{\circ} \mathrm{C}$ for $48 \mathrm{~h}$, the number of cfu was adjusted using the conversion table provided by the manufacturer and was expressed in as $\mathrm{cfu} / \mathrm{m}^{3}$.

For Coriolis ${ }^{\circledR} \mu$, a cone containing $15 \mathrm{~mL}$ of liquid substrate $(0.005 \%$ Triton $\mathrm{X}-100)$ was used according to the manufacturer's recommendations. After aspiration, the volume of liquid substrate was aeseptically transferred to a sterile container for culture-based investigations, and $0.5 \mathrm{~mL}$ of the original sampling solution and 1:10 dilutions were plated on PCA plates. The plates were incubated at $36 \pm 1{ }^{\circ} \mathrm{C}$ for $48 \mathrm{~h}$, and the average cfu was used to calculate the total airborne microbial load using the following equation $[24,25]$ :

$$
\mathrm{cfu} / \mathrm{m}^{3}=\frac{\mathrm{cfu}}{\text { Vplated aliquot }[\mathrm{mL}]} \times \frac{\text { dilution factor } \times \text { Vbuffer after sampling }[\mathrm{mL}]}{\text { Vair sample }\left[\mathrm{m}^{3}\right]}
$$

Passive sampling was performed using two sedimentation plates, 90-mm in diameter, which were exposed to the air for $1 \mathrm{~h}, 1 \mathrm{~m}$ above the floor on a Sed-3Unit ${ }^{\circledR}$ (MRC AG, CH-9450 Altstätten/SG) at least $1 \mathrm{~m}$ away from major obstacles. The results were expressed as the mean of the two plates to determine the IMA. Total viable count (TVC) was recorded in duplicate to ensure sampling accuracy, using PCA plates that we incubated at $36 \pm 1^{\circ} \mathrm{C}$ for $48 \mathrm{~h} \mathrm{[26].}$

\subsection{Particle Counts}

Airborne particles with a diameter $\geq 0.5 \mu \mathrm{m}$ and $\geq 5 \mu \mathrm{m}$ in size were counted with a laser particle counter (Climet CI 754; Rigel Srl, Rome, Italy), which was certified and validated in accordance with the ISO 21501-4:2007 [27] requirements. The suction volume was $75 \mathrm{~L} / \mathrm{min}$, and measurements were performed three times, $1 \mathrm{~m}$ above the floor, and were expressed as the number of particles per $\mathrm{m}^{3}$. We used a 10-s interval between each of the three samplings. Figure 2 shows the floor plan of a representative OT and the positions of the air and particulate samplers. During the in operation samplings, we placed the instruments at the end of the plenum to avoid interfering with the surgical activities.

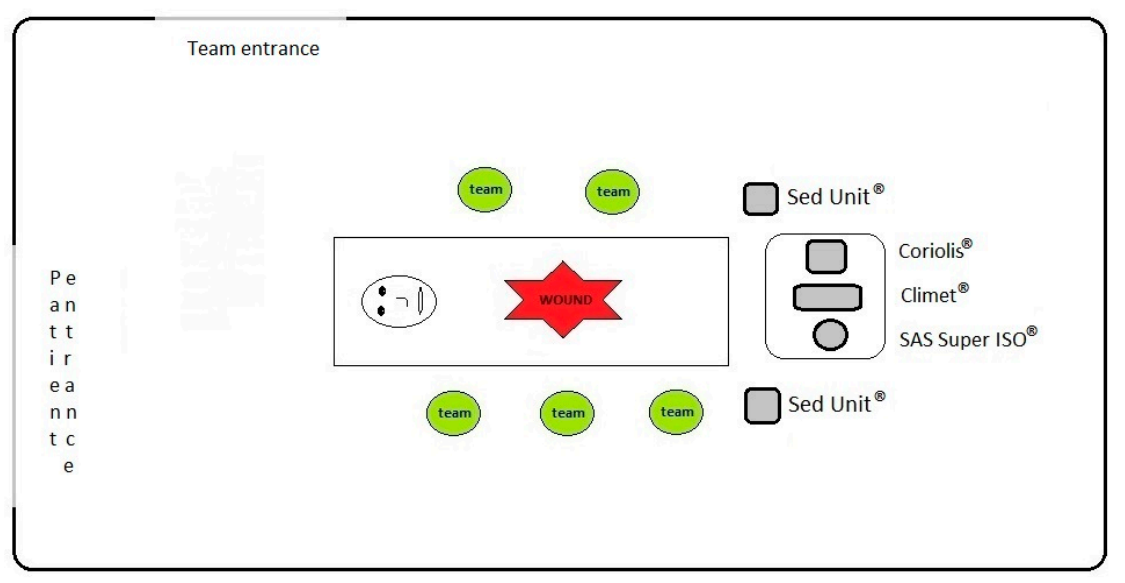

Figure 2. Position of the air sampling instruments in the operating theatres during the in operation samplings. 


\subsection{Statistical Analyses}

Continuous variables did not approach Gaussian distribution; therefore, they were reported as the median and interquartile range (IQR). Comparisons between groups were performed with nonparametric tests: Wilcoxon's and Kruskal-Wallis tests for independent groups, Wilcoxon's and Friedman's tests for nonindependent groups. Post-hoc comparisons were performed with the Conover test for multiple comparisons.

The relationships between variables were evaluated with Spearman's correlation coefficient; a partial Spearman's correlation was used to evaluate coefficients adjusted for other variables, such as particle size, number of people in the OT, number of door openings and the number of people involved in the surgery team.

Qualitative variables were analysed using the chi-square test or Fisher's exact test, as appropriate. The number of door openings was classified as: "always open" (i.e., constantly open) or "occasionally open" (indicating that doors were open only when a health worker came in or out of the OT). To evaluate the relationships between air quality and door opening, microbial counts were classified as $0 \mathrm{cfu} / \mathrm{m}^{3}$ or $>0 \mathrm{cfu} / \mathrm{m}^{3}$, and we defined two grades for passive sampling counts: 0 (zero) IMA and $>0$ (zero) IMA.

A $p$-value $<0.05$ indicated statistical significance. Analyses were performed using the statistical software MedCalc 18.6 (MedCalc Software, Mariakerke, Belgium) and SAS 9.4 (SAS Institute Inc., Cary, NC, USA).

\section{Results}

Among the 45 hospitals present in Apulia from 2015-2016, 35 orthopaedic OTs were part of a complex that provided adequate space for anaesthesia and surgery and were under positive pressure regarding the adjacent areas $(\geq 5 \mathrm{~Pa})$. The 35 orthopaedic OT systems with air treatment were equally distributed: 18 OTs were equipped with a T-OT and 17 with an M-OT. No unidirectional OTs were included in this study.

For each OT, the median number of doors was two for both M-OTs and T-OTs, and the door type (sliding or swinging) was similar. The doors were kept "always open" in $58.8 \%$ of M-OTs and in $55.6 \%$ of T-OTs. Regarding the "occasionally open" doors, the median number of openings for swinging doors was 16 in M-OTs and 17 in T-OTs, and the median number of openings for sliding doors was 11.5 in M-OTs and 16 in T-OTs. Table 1 shows the characteristics of M-OTs and T-OTs.

Table 1. Comparison of the characteristics between the mixed airflow (M-OTs) and turbulent airflow operating theatres (T-OTs). IQR = Interquartile Range.

\begin{tabular}{cccccc}
\hline \multirow{2}{*}{ Variables } & \multicolumn{2}{c}{ M-OTs $(\boldsymbol{N}=\mathbf{1 7})$} & \multicolumn{2}{c}{ T-OTs $(\boldsymbol{N}=\mathbf{1 8})$} & \multirow{2}{*}{$\boldsymbol{p}$-Value } \\
\cline { 2 - 5 } & Median & IQR & Median & IQR & \\
\hline DOORS & 2 & $1-2$ & 2 & $1-3$ & 0.9721 \\
Sliding doors & 1 & $1-1$ & 2 & $1-2$ & 0.1697 \\
Swinging doors & 0 & $0-1$ & 0 & $0-0$ & 0.0899 \\
Volume of OTs & 114 & $105-123$ & 140 & $114-170$ & 0.0729 \\
Surface of OTs & 38 & $34-42$ & 42 & $39-47.5$ & 0.1922 \\
Number of air changes/h & 15 & $15-26$ & 18.29 & $15-18.5$ & 0.8162 \\
\hline
\end{tabular}

The median number of people present in the OTs in operation was nine in both types of OT, with no statistically significant difference between M-OTs and T-OTs $(p>0.05)$.

Regarding microbiological data, 280 air samples (140 at rest and 140 in operation) were studied from the 35 OTs. With all systems used, the median value indicating bacterial contamination at rest was zero for both M-OTs and T-OTs. In operation, the median value with the SAS system was $15 \mathrm{cfu} / \mathrm{m}^{3}$ (M-OTs) and 23.5 (T-OTs) $\mathrm{cfu} / \mathrm{m}^{3}$ (IQR: 7.5-60 and 17-58, respectively). With the Coriolis ${ }^{\circledR} \mu$ system, the median values were $48 \mathrm{cfu} / \mathrm{m}^{3}$ in M-OTs and $10.5 \mathrm{cfu} / \mathrm{m}^{3}$ in T-OTs (IQR: 24-67.75 and 0-52, respectively); with the sedimentation plates, IMA values were 4 and 4.5 (range: 2.75-6 and 4-8, respectively) (Table 2). 
Table 2. Median values for bacterial contamination at rest and in operation obtained by active (SAS, Coriolis ${ }^{\circledR} \mu$ ) and passive (sedimentation plates) methods.

\begin{tabular}{|c|c|c|c|c|c|c|c|c|}
\hline \multirow{3}{*}{ Method } & \multicolumn{4}{|c|}{ At Rest } & \multicolumn{4}{|c|}{ In Operation } \\
\hline & \multicolumn{2}{|c|}{ Mixed } & \multicolumn{2}{|c|}{ Turbulent } & \multicolumn{2}{|c|}{ Mixed } & \multicolumn{2}{|c|}{ Turbulent } \\
\hline & Median & IQR & Median & IQR & Median & IQR & Median & IQR \\
\hline SAS $\left(\mathrm{cfu} / \mathrm{m}^{3}\right)$ & $0^{\$}$ & $0-2$ & $0.5^{\#}$ & $0-3$ & $15^{\$}$ & $7.5-60$ & $23.5^{\#}$ & $17-58$ \\
\hline Coriolis ${ }^{\circledR} \mu\left(\mathrm{cfu} / \mathrm{m}^{3}\right)$ & $0^{\wedge}$ & $0-0$ & 0 & $0-0$ & $48^{\wedge}$ & $24-67.75$ & 10.5 & $0-52$ \\
\hline Settling plates (IMA) & 0 * & $0-1$ & $0 \S$ & $0-2$ & $4^{*}$ & $2.75-6$ & $4.5 \S$ & $4-8$ \\
\hline
\end{tabular}

A statistically significant increase in bacterial contamination was observed when comparing samples at rest vs in operation for both M-OTs and T-OTs and with all methods.

Regarding particle data, there were no statistically significant differences in the $0.5 \mu \mathrm{m}$ particle counts between M-OTs and T-OTs at rest or in operation. Table 3 shows the partial Spearman's correlation coefficient between microbial counts in operation and for each of the following variables: particles, number of access doors in the OT and number of people present in the OT.

Table 3. Partial Spearman's correlation coefficient for comparisons between particle size, number of access doors to the operating theatres and the number of people during in operation measurements.

\begin{tabular}{|c|c|c|c|c|c|c|}
\hline \multirow{3}{*}{ Variables } & \multicolumn{6}{|c|}{ Mixed Airflow } \\
\hline & \multicolumn{2}{|c|}{ SAS } & \multicolumn{2}{|c|}{ Coriolis ${ }^{\circledR} \mu$} & \multicolumn{2}{|c|}{ Settling Plates } \\
\hline & $\begin{array}{c}\text { Spearman } \\
\text { Coeff. }\end{array}$ & $p$-Value & $\begin{array}{c}\text { Spearman } \\
\text { Coeff. }\end{array}$ & $p$-Value & $\begin{array}{c}\text { Spearman } \\
\text { Coeff. }\end{array}$ & $p$-Value \\
\hline Particles $\geq 0.5 \mu \mathrm{m}$ & -0.071 & 0.818 & 0.045 & 0.8839 & -0.125 & 0.6848 \\
\hline Particles $\geq 5 \mu \mathrm{m}$ & 0.015 & 0.9631 & 0.68 & 0.0158 & 0.006 & 0.9854 \\
\hline Number of doors & 0.048 & 0.8822 & 0.32 & 0.3147 & -0.063 & 0.8452 \\
\hline Number of people & 0.44 & 0.1496 & -0.15 & 0.6489 & 0.26 & 0.4228 \\
\hline \multirow{3}{*}{ Variables } & \multicolumn{6}{|c|}{ Turbulent Airflow } \\
\hline & \multicolumn{2}{|c|}{ SAS } & \multicolumn{2}{|c|}{ Coriolis ${ }^{\circledR} \mu$} & \multicolumn{2}{|c|}{ Settling plates } \\
\hline & $\begin{array}{c}\text { Spearman } \\
\text { Coeff. }\end{array}$ & $p$-Value & $\begin{array}{c}\text { Spearman } \\
\text { Coeff. }\end{array}$ & $p$-Value & $\begin{array}{c}\text { Spearman } \\
\text { Coeff. }\end{array}$ & $p$-Value \\
\hline Particles $\geq 0.5 \mu \mathrm{m}$ & 0.24 & 0.4542 & 0.62 & 0.0316 & 0.23 & 0.4786 \\
\hline$\geq 5 \mu \mathrm{m}$ & 0.47 & 0.1015 & 0.47 & 0.1041 & 0.16 & 0.5988 \\
\hline Number of doors & -0.12 & 0.6972 & -0.27 & 0.3666 & 0.31 & 0.3002 \\
\hline Number of people & 0.17 & 0.5775 & 0.34 & 0.2542 & 0.34 & 0.4315 \\
\hline
\end{tabular}

SAS = Surface Air System.

Statistically significant correlation were obtained for the bacterial count regarding Coriolis ${ }^{\circledR} \mu$ and particles $\geq 5 \mu \mathrm{m}\left(\mathrm{r}_{\mathrm{S}}=0.68, p=0.0158\right)$, in M-OTs in operation. These results show a direct correlation between particle counts using Coriolis ${ }^{\circledR} \mu$ and $\geq 5 \mu \mathrm{m}$ particles; the bacterial count and particles were concordantly high.

M-OTs had a median number of 1 (range 1-4) sliding doors, and $41.2 \%$ were always open; in 10 OTs the median number of openings was 10 (range 5-31). T-OTs had a median number of 2 sliding doors (range $0-3$ ), and $44.4 \%$ were always open. There was no statistically significant difference in the number of door openings between T-OTs and M-OTs $(p=0.5401)$. Table 4 shows the percentages of OTs by door openings and class of bacterial counts, stratified by airflow and sampling systems. There was no statistically significant relationship between door opening and bacterial count by any method or in M-OTs and T-OTs. This association was not statistically significant for mixed airflow $(p=0.134769)$ or turbulent airflow $(p=1)$. 
Table 4. The number of door openings and bacterial counts stratified by airflow and sampling system.

\begin{tabular}{|c|c|c|c|c|c|}
\hline \multicolumn{6}{|c|}{ Mixed Airflow } \\
\hline & \multicolumn{2}{|c|}{ Door Openings $(\mathrm{OTs}=10)$} & \multicolumn{2}{|c|}{ Doors Kept Open (OTs = 7) } & \multirow{2}{*}{$p$-Value } \\
\hline & No. & $\%$ & No. & $\%$ & \\
\hline \multicolumn{6}{|c|}{ SETTLING PLATES (IMA/plate) } \\
\hline 0 & rs & rs & 0 & 0.0 & \multirow{2}{*}{1} \\
\hline$>0$ & 10 & 100.0 & 7 & 100.0 & \\
\hline \multicolumn{6}{|c|}{ SAS $\left(\mathrm{cfu} / \mathrm{m}^{3}\right)$} \\
\hline 0 & 0 & 0.0 & 0 & 0.0 & \multirow{2}{*}{0.134769} \\
\hline$>0$ & 10 & 100.0 & 7 & 100.0 & \\
\hline \multicolumn{6}{|c|}{ Coriolis ${ }^{\circledR} \mu\left(\mathrm{cfu} / \mathrm{m}^{3}\right)$} \\
\hline 0 & 0 & 0.0 & 2 & 28.6 & \multirow{2}{*}{0.1544} \\
\hline$>0$ & 10 & 100.0 & 5 & 71.4 & \\
\hline \multicolumn{6}{|c|}{ Turbulent Airflow } \\
\hline & \multicolumn{2}{|c|}{ Door Openings (OTs = 10) } & \multicolumn{2}{|c|}{ Doors Kept Open (OTs = 7) } & \multirow{2}{*}{$p$-Value } \\
\hline & No. & $\%$ & No. & $\%$ & \\
\hline \multicolumn{6}{|c|}{ SETTLING PLATES (IMA/plate) } \\
\hline 0 & 0 & 0.0 & 1 & 12.5 & \multirow{2}{*}{0.44444} \\
\hline$>0$ & 10 & 100.0 & 7 & 87.5 & \\
\hline \multicolumn{6}{|c|}{ SAS $\left(\mathrm{cfu} / \mathrm{m}^{3}\right)$} \\
\hline 0 & 0 & 0.0 & 0 & 0.0 & \multirow[b]{2}{*}{1} \\
\hline$>0$ & 10 & 100.0 & 8 & 100.0 & \\
\hline Coriolis ${ }^{\circledR} \mu$ & & & & & \\
\hline 0 & 6 & 60.0 & 3 & 37.5 & \multirow{2}{*}{0.6372} \\
\hline$>0$ & 4 & 40.0 & 5 & 62.5 & \\
\hline
\end{tabular}

OTs = operating theatres; IMA = index microbial air contamination; cfu = colony-forming unit; SAS = Surface Air System.

Regarding particle data, regression analysis for associations between bacterial counts and particle size showed a nonunivocal pattern (Figure 3a,b).

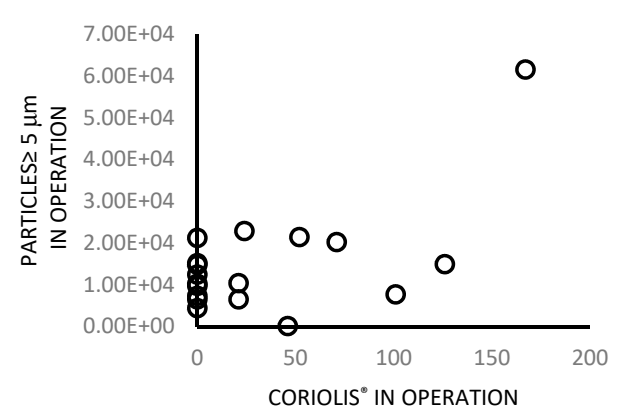

(a)

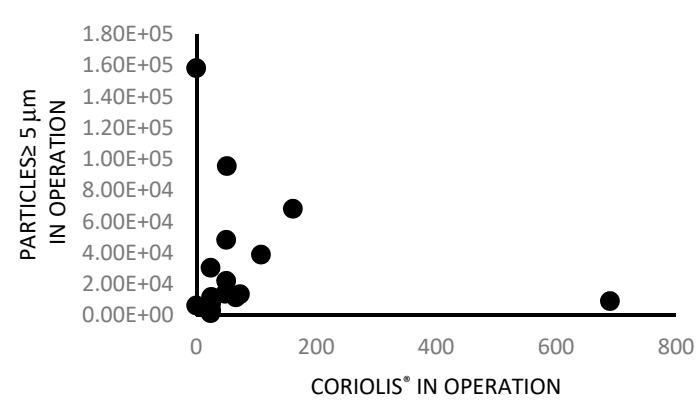

(b)

Figure 3. (a) Scatter plots evaluating the relationship between counts using the Coriolis ${ }^{\circledR} \mu$ and particles $\geq 5 \mu \mathrm{m}\left(\mathrm{r}_{\mathrm{S}}=0.68, p\right.$-value $\left.=0.0158\right)$ in operating theatres with mixed airflow. $(\mathbf{b})$ Scatter plots evaluating the relationship between counts using the Coriolis ${ }^{\circledR} \mu$ and $\geq 5 \mu \mathrm{m}$ particles $\left(\mathrm{r}_{\mathrm{S}}=0.47\right.$, $p$-value $=0.1041)$ in operating theatres with turbulent airflow.

We deleted the number of people in the OTs, the number of doors (sliding and swinging) and the number of openings from any model when these variables resulted in no statistical significance in any model. The type of airflow was not statistically significant, but we left this variable in the models, to evaluate its effect. 
At rest, the effect of particle size on Coriolis ${ }^{\circledR} \mu$ counts could not be determined because $85 \%$ of OTs (30/35) had a count of zero.

\section{Discussion}

This study evaluated air quality in orthopaedic OTs, both at rest and in operation during the first surgical procedure of the day, using different sampling systems and data for different types of HVAC systems. The difference between TVC mean values in M-OTs and T-OTs was not statistically significant. We used both active and passive sampling methods $[17,26]$ and in addition to traditional sampling methods, we used the Coriolis ${ }^{\circledR} \mu$ active sampler because some authors showed that Coriolis ${ }^{\circledR} \mu$ had a higher sensitivity when the study focused on microorganisms that were difficult to isolate from air samples [28].

In our study, we found a statistically significant correlation between the microbial count obtained by Coriolis ${ }^{\circledR} \mu$ and the particle count; M-OTs showed a higher microbial count if particles $\geq 5 \mu \mathrm{m}$ were considered. Based on these results, we hypothesized that larger particles carry a greater number of microbes. However, these results were not confirmed when the SAS system was used, although this is also an active sampling method, similar to other studies showing different results when different samplers were used $[29,30]$. The role of airborne particles as a source of contamination, especially during clean surgical procedures, is still debated and also although other authors studied the problem of correlation between microbial count and particles, the question is yet unresolved [2,20,31,32].

No bacterial contamination appeared in OTs at rest with any sampler we used. Although other authors reported high contamination values before daily activities began in the OTs [33-36], our data suggest effective sanitation measures in the OTs in our study and correct functioning of the ventilation systems. According to a previous study [22], air quality at rest confirmed the effectiveness of the sanitation measures of the OTs and of the HVAC systems.

Higher bacterial counts appeared in operation, in our OTs, using both active and passive sampling methods. The median values were low, although differences in bacterial counts before and during surgery were significant for all systems. Indeed, the microbiological results obtained in operation by the SAS system showed median values of $<15 \mathrm{cfu} / \mathrm{m}^{3}$ in M-OTs and $23.5 \mathrm{cfu} / \mathrm{m}^{3}$ in T-OTs; i.e., lower than the limit of contamination recommended by ISPESL guidelines [17] in OTs at rest $\left(<35 \mathrm{cfu} / \mathrm{m}^{3}\right)$. These results suggest that the current recommended value appears to be too high for conventional OTs. Most likely, in accordance with the ISPESL guidelines [17], only by performing repeated sampling over time and acquiring a historical database for each type of OT, would it be possible to calculate the alert values. Currently, air sampling methods are not standardized; therefore, it is difficult to compare results obtained from different samplers. The debate on the choice of these systems is still open.

Regarding the presence of people in the OTs as a factor influencing airborne contamination during surgical procedures, some authors indicated that the number of members in the surgical team had the greatest impact on both airborne bacteria and particle counts [15,32]. In our study, Spearman's correlation coefficient analysis did not reveal a significant association between the number of people (median $=9$ ) and the airborne bacterial count in both M-OTs and T-OTs. Even when the doors (sliding or swinging) were always open, the bacterial load was very low, probably because the bacterial load was equal to the adjacent area. The impact of door openings on air quality was analysed by other authors [37,38] but clinical confirmation remains complex. Some authors [39] found no significant differences in the airborne bacterial count between closed doors.

\section{Conclusions}

In conclusion, our results did not show significant differences between our measured variables, and initial observations support the hypothesis that air quality in OTs is not affected by sampling methods or different ventilation systems. At rest, our results confirmed the effectiveness of the HVAC in the OTs, in operation, TVC values were within the recommended threshold. Further study will help assess other aspects of this study using a more detailed protocol and repeated measurements over time. 
Author Contributions: M.T.M., G.C., O.D.G., C.N. and C.P. (Cesira Pasquarella) conceived and designed the study; F.A., A.D., G.D., S.R., A.M., S.M., C.P. (Chrysovalentinos Pousis) and M.L. performed the sampling and microbiological investigation; P.T. and G.S. analysed the data; M.T.M., G.C. and C.N. wrote the paper; O.D.G., D.D., R.A. and C.P. (Cesira Pasquarella) revised the manuscript. All authors read and approved the final manuscript.

Funding: Apulia Regional Government (DGR No. 867 of 29 April 2015) provided financial support for this research.

Acknowledgments: The authors thank all the members of the Apulia Regional Government for their close cooperation during the development of this surveillance study and all colleagues, physicians and nurses working in the following participating hospitals: Ente Ecclesiastico Francesco Miulli, Acquaviva delle Fonti, Bari; Ospedale della Murgia Fabio Perinei, Altamura, Bari; Ospedale Lorenzo Bonomo, Andria (BT); AOU Policlinico, Bari; PO Di Venere, Bari; Ospedale Giovanni XXIII, Bari; PO San Paolo, Bari; PO Monsignor Dimiccoli, Barletta (BT); PO Vittorio Emanuele II, Bisceglie (BT); PO Antonio Perrino, Brindisi; PO Francesco Ferrari, Casarano, Lecce; PO Occidentale, Castellaneta, Taranto; Ospedale San Giuseppe da Copertino, Copertino, Lecce; Ospedale Umberto I, Corato, Bari; AOU Ospedali Riuniti, Foggia; PO di Francavilla Fontana, Francavilla Fontana, Brindisi; Ospedale Santa Caterina Novella, Galatina, Lecce; Ospedale Sacro Cuore di Gesù, Gallipoli, Lecce; Ospedale Vito Fazzi, Lecce; Ospedale San Camillo de Lellis, Manfredonia, Foggia; PO Valle d'Itria, Martina Franca, Taranto; Ospedale Don Tonino Bello, Molfetta, Bari; Ospedale San Giacomo, Monopoli, Bari; PO di Ostuni, Ostuni, Brindisi; Ospedale Santa Maria degli Anglei, Putignano, Bari; IRCCS Casa Sollievo della Sofferenza, San Giovanni Rotondo, Foggia; PO Teresa Masselli, San Severo, Foggia; PO Veris Delli Ponti, Scorrano, Lecce; PO SS Annunziata, Taranto; Ospedale Cardinale Giovanni Panico, Tricase, Lecce. T We thank Jane Charbonneau, DVM, from Edanz Group (www.edanzediting.com/ac) for editing a draft of this manuscript.

Conflicts of Interest: The authors declare no conflict of interest.

\section{References}

1. Andersen, B.M.; Solheim, N. Occlusive scrub suits in operating theaters during cataract surgery: Effect on airborne contamination. Infect. Control Hosp. Epidemiol. 2002, 23, 218-220. [CrossRef] [PubMed]

2. Scaltriti, S.; Cencetti, S.; Rovesti, S.; Marchesi, I.; Bargellini, A.; Borella, P. Risk factors for particulate and microbial contamination of air in operating theatres. J. Hosp. Infect. 2007, 66, 320-326. [CrossRef] [PubMed]

3. Wan, G.H.; Chung, F.F.; Tang, C.S. Long-term surveillance of air quality in medical center operating rooms. Am. J. Infect. Control 2011, 39, 302-308. [CrossRef] [PubMed]

4. Spagnolo, A.M.; Ottria, G.; Amicizia, D.; Perdelli, F.; Cristina, M.L. Operating theatre quality and prevention of surgical site infections. J. Prev. Med. Hyg. 2013, 54, 131-137. [PubMed]

5. Cristina, M.L.; Sartini, M.; Schinca, E.; Ottria, G.; Spagnolo, A.M. Operating room environment and surgical site infections in arthroplasty procedures. J. Prev. Med. Hyg. 2016, 57, 142-148.

6. Gelaw, K.A.; Aweke, A.M.; Astawesegn, F.H.; Demissie, B.W.; Zeleke, L.B. Surgical site infection and its associated factors following cesarean section: A cross sectional study from a public hospital in Ethiopia. Patient Saf. Surg. 2017, 11, 18. [CrossRef] [PubMed]

7. Badia, J.M.; Casey, A.L.; Petrosillo, N.; Hudson, P.M.; Mitchell, S.A.; Crosby, C. Impact of surgical site infection on healthcare costs and patient outcomes: A systematic review in six European countries. J. Hosp. Infect. 2017, 96, 1-15. [CrossRef] [PubMed]

8. World Health Organization. Global Guidelines for the Prevention of Surgical Site Infection; WHO: Geneva, Switzerland, 2016; p. 158.

9. Zimmerli, W.; Trampuz, A.; Ochsner, P.E. Prosthetic-joint infections. N. Engl. J. Med. 2004, 351, $1645-1654$. [CrossRef] [PubMed]

10. Kurtz, S.M.; Lau, E.; Watson, H.; Schmier, J.K.; Parvizi, J. Economic burden of periprosthetic joint infection in the United States. J. Arthroplasty 2012, 27, 61-65. [CrossRef] [PubMed]

11. Kurtz, S.M.; Ong, K.L.; Schmier, J.; Mowat, F.; Saleh, K.; Dybvik, E.; Kärrholm, J.; Garellick, G.; Havelin, L.I.; Furnes, O. Future clinical and economic impact of revision total hip and knee arthroplasty. J. Bone Joint Surg. Am. 2007, 89, 144-151. [PubMed]

12. Torre, M.; Carrani, E.; Luzi, I.; Ceccarelli, S.; Laricchiuta, P. Registro Italiano ArtroProtesi. Report Annuale 2018, 1st ed.; Il Pensiero Scientifico Editore: Roma, Italy, 2018.

13. Friberg, B.; Friberg, S.; Burman, L.G. Inconsistent correlation between aerobic bacterial surface and air counts in operating rooms with ultraclean laminar air flows: Proposal of a new bacteriological standard for surface contamination. J. Hosp. Infect. 1999, 42, 287-293. [CrossRef] [PubMed] 
14. Bischoff, P.; Kubilay, N.Z.; Allegranzi, B.; Egger, M.; Gastmeier, P. Effect of laminar airflow ventilation on surgical site infections: A systematic review and meta-analysis. Lancet Infect. Dis. 2017, 17, 553-561. [CrossRef]

15. Pasquarella, C.; Barchitta, M.; D’Alessandro, D.; Cristina, M.L.; Mura, I.; Nobile, M.; Auxilia, F.; Agodi, A.; Avondo, S.; Basile, G.; et al. Heating, ventilation and air conditioning (HVAC) system, microbial air contamination and surgical site infection in hip and knee arthroplasties: The GISIO-SItI Ischia study. Ann. Ig. 2018, 30, 22-35. [PubMed]

16. Health Technical Memorandum 03-01. Specialised Ventilation for Healthcare Premises_Part A: Design and Validation; TSO: Edinburgh, UK, 2007.

17. ISPESL (Istituto Superiore per la Prevenzione e la Sicurezza del Lavoro). Linee Guida Sugli Standard di Sicurezza e di Igiene Del Lavoro Nel Reparto Operatorio; ISPESL: Rome, Italy, 2009.

18. Die Spitäler der Schweiz. Anhang 4 zur KlatAS. Beschreibung der IMA-Methode.Stand. 2007. Available online: http://www.hplus.ch/fileadmin/user_upload/Betriebswirtschaft/Spitalinfrastruktur/ deutsch/Anhang\%204\%20Standard\%20IMA.pdf (accessed on 29 June 2019).

19. Pittet, D.; Ducel, G. Infectious risk factors related to operating rooms. Infect. Control Hosp. Epidemiol. 1994, 15, 456-462. [CrossRef]

20. Cristina, M.L.; Spagnolo, A.M.; Sartini, M.; Panatto, D.; Gasparini, R.; Orlando, P.; Ottria, G.; Perdelli, F. Can Particulate Air Sampling Predict Microbial Load in Operating Theatres Arthroplasty? PLoS ONE 2012, 7, e52809. [CrossRef] [PubMed]

21. Birgand, G.; Toupet, G.; Rukly, S.; Antoniotti, G.; Dechamps, M.N.; Lepelletier, D.; Pornet, C.; Stern, J.B.; Vandamme, Y.M.; Van der Mee-Marquet, N. Air contamination for predicting wound contamination in clean surgery: A large multicenter study. Am. J. Infect. Control 2015, 43, 516-521. [CrossRef]

22. D’Amico, A.; Montagna, M.T.; Caggiano, G.; De Giglio, O.; Rutigliano, S.; Lopuzzo, M.; Mascipinto, S.; Napoli, C.; Currà, E.; D'Alessandro, D. Observational study on hospital building heritage and microbiological air quality in the orthopedic operating theater: The IM.PA.C.T. Project. Ann. Ig. 2019, 31, 482-495.

23. Standardization IOS. Cleanrooms and Associated Controlled Environments: Biocontamination Control, Part 1: General Principles and Methods, ISO 14698-1:2003; ISO: Geneva, Switzerland, 2003.

24. Carvalho, E.; Sindt, C.; Verdier, A.; Galan, C.; O’Donoghue, L.; Parks, S.; Thibaudon, M. Performance of the Coriolis air sampler, a high-volume aerosol-collection system for quantification of airborne spores and pollen grains. Aerobiologia 2008, 24, 191-201. [CrossRef]

25. Ahmed, M.F.; Schulz, J.; Hartung, J. Air samplings in a Campylobacter jejuni positive laying hen flock. Ann. Agric. Environ. Med. 2013, 20, 16-20.

26. Pasquarella, C.; Pitzurra, O.; Savino, A. The index of microbial air contamination. J. Hosp. Infect. 2000, 46, 241-256. [CrossRef]

27. IOS. Determination of Particle Size Distribution-Single Particle Light Interaction Methods-Part 4: Light Scattering Airborne Particle Counter for Clean Spaces. ISO 21501-1:2007 (E); ISO: Geneva, Switzerland, 2007.

28. Montagna, M.T.; De Giglio, O.; Cristina, M.L.; Napoli, C.; Pacifico, C.; Agodi, A.; Baldovin, T.; Casini, B.; Coniglio, M.A.; D'Errico, M.M.; et al. Evaluation of Legionella air contamination in healthcare facilities by different sampling methods: An Italian multicenter study. Int. J. Environ. Res. Public Health. 2017, 14, 670. [CrossRef] [PubMed]

29. Lee, K.S.; Bartlett, K.H.; Brauer, M.; Stephens, G.M.; Black, W.A.; Teschke, K. A field comparison of four samplers for enumerating fungal aerosols I. Sampling characteristics. Indoor Air. 2004, 14, 360-366. [CrossRef] [PubMed]

30. Pasquarella, C.; Albertini, R.; Dall'aglio, P.; Saccani, E.; Sansebastiano, G.E.; Signorelli, C. Air microbial sampling: The state of the art. Ig. Sanita Pubbl. 2008, 64, 79-120. [PubMed]

31. Landrin, A.; Bissery, A.; Kac, G. Monitoring air sampling in operating theatres: Can particle counting replace microbiological sampling? J. Hosp. Infect. 2005, 61, 27-29. [CrossRef] [PubMed]

32. Pankhurst, L.J.; Taylor, J.; Cloutman-Green, E.A.; Hartley, J.C.; Lai, K.M. Can clean-room particle counters be used as an infection control tool in hospital operating theatres? Indoor Built Environ. 2012, 21, 381-391. [CrossRef]

33. Napoli, C.; Marcotrigiano, V.; Montagna, M.T. Air sampling procedures to evaluate microbial contamination: A comparison between active and passive methods in operating theatres. BMC Public Health. 2012, 12, 594. [CrossRef] [PubMed] 
34. Napoli, C.; Tafuri, S.; Montenegro, L.; Cassano, M.; Notarnicola, A.; Lattarulo, S.; Montagna, M.T.; Moretti, B. Air sampling methods to evaluate microbial contamination in operating theatres: Results of a comparative study in an orthopaedics department. J. Hosp. Infect. 2012, 80, 128-132. [CrossRef]

35. Pasquarella, C.; Veronesi, L.; Napoli, C.; Castiglia, P.; Liguori, G.; Rizzetto, R.; Torre, I.; Righi, E.; Farruggia, P.; Tesauro, M.V.; et al. Microbial environmental contamination in Italian dental clinics: A multicenter study yielding recommendations for standardized sampling methods and threshold values. Sci. Total Environ. 2012, 420, 289-299. [CrossRef]

36. Caggiano, G.; Napoli, C.; Coretti, C.; Lovero, G.; Scarafile, G.; De Giglio, O.; Montagna, M.T. Mold contamination in a controlled hospital environment: A 3-year surveillance in southern Italy. BMC Infect. Dis. 2014, 14, 595. [CrossRef]

37. Shaw, B.H.; Whyte, W. Air movement through doorways: The influence of temperature and its control by forced airflow. Build Serv. Eng. 1974, 42, 210-218.

38. Wilson, D.J.; Kiel, D.E. Gravity-driven counterflow through an open door in a sealed room. Build Environ. 1990, 25, 379-388. [CrossRef]

39. Ritter, M.A.; Eitzen, H.; French, M.L.; Hart, J.B. The operating room environment as affected by people and the surgical face mask. Clin. Orthop. Relat. Res. 1975, 111, 147-150. [CrossRef] [PubMed]

(C) 2019 by the authors. Licensee MDPI, Basel, Switzerland. This article is an open access article distributed under the terms and conditions of the Creative Commons Attribution (CC BY) license (http://creativecommons.org/licenses/by/4.0/). 